\title{
X-linked intellectual disability, Stevenson type
}

INSERM

\section{Source}

INSERM. (1999). Orphanet: an online rare disease and orphan drug data base. $\underline{X-l i n k e d}$ intellectual disability, Stevenson type. ORPHA:85325

X-linked intellectual disability, Stevenson type is characterised by intellectual deficit, hypotonia, absent deep tendon reflexes, tapered fingers and excessive fingerprint arches, genu valgum, a characteristic face and small teeth. It has been described in four males from two generations of one family. The causative gene appears to be located in the $\mathrm{q} 13$ region of the $\mathrm{X}$ chromosome. 